\title{
KADAR HEMOGLOBIN PADA PASIEN GAGAL GINJAL KRONIK YANG MENJALANI HEMODIALISIS
}

\author{
Ardiya Garini* \\ Jurusan Analis Kesehatan Poltekkes Palembang \\ Diterima :20 Desember 2018 Direvisi : 22 Desember 2018 Disetujui : 26 Desember 2018
}

\begin{abstract}
ABSTRAK
Latar belakang : Gagal ginjal merupakan kondisi yang mengakibatkan ginjal kehilangan kemampuannya untuk mempertahankan volume dan komposisi cairan tubuh dalam keadaan asupan makan normal. Faktor utama penyebab anemia pada gagal ginjal kronik disebabkan berkurangnya sel darah merah akibat turunnya kadar hormon eritropoetin (EPO). Salah satu terapi pada pasien gagal ginjal kronik adalah dengan hemodialisis, tetapi cara ini dapat menimbulkan komplikasi diantaranya anemia yang semakin parah.

Tujuan : untuk mengetahui gambaran kadar hemoglobin pada pasien gagal ginjal kronik yang menjalani hemodialisis berdasarkan umur, jenis kelamin, lama sakit dan lama hemodialisis. Jenis penelitian yang digunakan adalah survey deskriftif dengan pendekatan cross sectional. Tempat penelitian di RSI Siti Khodijah Palembang dengan jumlah 48 sampel. Hasil : Rata-rata kadar hemoglobin $=8,065 \mathrm{gr} /$ dl. Rata-rata kadar hemoglobin perempuan $=7,794 \mathrm{gr} / \mathrm{dl}$, laki-laki $=8,213 \mathrm{gr} / \mathrm{dl}$ Rata-rata kadar hemoglobin remaja $=6,150 \mathrm{gr} / \mathrm{dl}$, dewasa $=7,831 \mathrm{gr} / \mathrm{dl}$, lansia 8,273 gr/dl. Rata-rata kadar hemoglobin dengan lama sakit $\leq 3$ bulan $=6,750 \mathrm{gr} / \mathrm{dl}$ dan $>3$ bulan $=8,122 \mathrm{gr} / \mathrm{dl}$. Rata-rata kadar hemoglobin dengan lama hemodialisis $\leq 12$ bulan $=7,600 \mathrm{gr} / \mathrm{dl},>12$ bulan $=8,186 \mathrm{gr} / \mathrm{dl}$.

Kesimpulan : Kadar hemoglobin yang rendah didapat pada pasien jenis kelamin perempuan, berumur remaja, lama sakit $\leq 3$ bulan dan lama hemodialisis $\leq 12$ bulan.
\end{abstract}

Kata kunci: gagal ginjal kronik, kadar hemoglobin

\section{PENDAHULUAN}

Gagal ginjal merupakan kondisi yang mengakibatkan ginjal kehilangan kemampuannya untuk mempertahankan volume dan komposisi cairan tubuh dalam keadaan asupan makan normal. gagal ginjal kronik berlangsung perlahan-lahan selama tiga bulan atau lebih dan dapat menyebabkan gagal ginjal yang permanen. Sampai saat ini ada tiga jenis terapi yang tersedia yaitu hemodialisis, peritorenal dialisis dan transplantasi ginjal (Baradero, 2008; PERNEFRI, 2012). Hemodialisis adalah pengalihan darah pasien dari tubuhnya melalui alat dialiser yang terjadi secara difusi dan ultrafiltrasi, kemudian darah kembali lagi kedalam tubuh pasien. Tujuan hemodialisis untuk membersihkan darah dari produk sisa-sisa metabolisme dan kelebihan air (Smeltzer, 2006; Baradero, 2008).

Walaupun hemodialisis merupakan terapi yang cukup efektif untuk pasien gagal ginjal kronik, tetapi setelah menjalani hemodialisis beberapa komplikasi bisa juga ditemukan seperti anemia, meningkatnya kecenderungan perdarahan dan infeksi. Anemia ini bisa disebabkan karena kehilangan darah akibat pengambilan darah untuk pemeriksaan laboratorium atau darah yang terperangkap atau tertinggal di alat hemodialisa, serta defisiensi zat besi dan zat nutrisi lainnya (Sekarwana, 2004; Afsar, 2010).

Untuk mengevaluasi anemia pada pasien gagal ginjal kronik, National Kidney Foundation merekomendasikan pemeriksaan laboratorium yang meliputi 
pemeriksaan darah lengkap (kadar hemoglobin, indeks eritrosit, jumlah dan jenis lekosit, dan jumlah trombosit), jumlah retikulosit absolut, kadar ferritin, saturasi transferin, kadar vitamin B12 dan kadar asam folat. Anemia merupakan kadar hemoglobin $\leq 12 \mathrm{~g} / \mathrm{dl}$ pada wanita dan $\leq 13,0 \mathrm{~g} / \mathrm{dl}$ pada pria dan wanita menopause (NKF, 2006). Berdasarkan tingkat keparahannya (severity), anemia dikelompokkan ke dalam kriteria ringan, sedang dan berat (WHO, 2011; KDIGO, 2012).

Beberapa penelitian yang pernah dilakukan untuk mengetahui anemia pada pasien gagal ginjal kronik sesudah menjalani hemodialisis antara lain oleh Afshar (2010), Bhatta (2011), Runtung (2013). Penelitian juga menunjukkan kejadian anemia pada pasien gagal ginjal kronik ini dipengaruhi oleh umur, jenis kelamin, lama sakit, dan lama hemodialisis (Balalio, 2012; Oktiadewi, 2012, Adiatma, 2014). Tetapi dari data yang ada, menunjukkan masih sedikitnya penelitian yang membahas tingkat keparahan anemia pada pasien gagl ginjal kronik.

Dari latar belakang di atas maka dilakukan penelitian untuk mengetahui kadar hemoglobin pada pasien gagal ginjal kronik yang menjalani hemodialisis.

\section{TUJUAN}

Diketahuinya kadar hemoglobin pada pasien gagal ginjal kronik yang menjalani hemodialisis berdasarkan jenis kelamin. umur. berdasarkan lama sakit Dan berdasarkan lama hemodialisis.

\section{METODE PENELITIAN}

Jenis penelitian yang digunakan adalah survey deskriftif dengan pendekatan cross sectional. Tempat penelitian di RSI Siti Khodijah Palembang dengan jumlah 48 sampel. Waktu penelitian dilakukan Juni-Desember 2016.

Kriteria Inklusi

1. Pasien dengan diagnosis gagal ginjal kronik yang menjalani hemodialisis reguler (pernah menjalani hemodialisis sebelumnya) di RSI Siti Khodijah Palembang

2. Usia $\geq 18$ tahun

3. Kadar hemoglobin pada laki-laki $\leq 12,9$ gr/dl dan perempuan $\leq 11,9$

4. Menandatangani informed consent.

Kriteria Ekslusi

1. Pasien yang belum pernah menjalani hemodialisis sebelumnya di RSI Siti Khodijah Palembang

2. Pasien yang menolak.

\section{HASIL}

Tabel 1

Kadar Hemoglobin Pada Pasien Gagal Ginjal Kronik yang Menjalani Hemodialisis Berdasarkan Jenis Kelamin

\begin{tabular}{ccccccc}
\hline $\begin{array}{c}\text { Jenis } \\
\text { Kelamin }\end{array}$ & n & $\begin{array}{c}\text { Mean } \\
(\mathbf{g r} / \mathbf{d l})\end{array}$ & $\begin{array}{c}\text { Median } \\
(\mathbf{g r} / \mathbf{d l})\end{array}$ & $\begin{array}{c}\text { SD } \\
(\mathbf{g r} / \mathbf{d l})\end{array}$ & $\begin{array}{c}\text { Min } \\
(\mathbf{g r} / \mathbf{d l})\end{array}$ & $\begin{array}{c}\text { Max } \\
(\mathbf{g r} / \mathbf{d l})\end{array}$ \\
\hline Laki-laki & 31 & 8,213 & 8,400 & 1,5605 & 4,6 & 12,1 \\
\hline Perempuan & 17 & 7,794 & 8,200 & 1,4307 & 5,1 & 10,0 \\
\hline
\end{tabular}

Tabel 2

Tingkat Keparahan Anemia Pada Pasien Gagal Ginjal Kronik yang Menjalani Hemodialisis Berdasarkan Umur

\begin{tabular}{ccccccc}
\hline Umur & $\mathbf{n}$ & $\begin{array}{c}\text { Mean } \\
\text { (gr/dl) }\end{array}$ & $\begin{array}{c}\text { Median } \\
(\mathbf{g r} / \mathbf{d l})\end{array}$ & $\begin{array}{c}\text { SD } \\
(\mathbf{g r} / \mathbf{d l})\end{array}$ & $\begin{array}{c}\text { Min } \\
(\mathbf{g r} / \mathbf{d l})\end{array}$ & $\begin{array}{c}\text { Max } \\
(\mathbf{g r} / \mathbf{d l})\end{array}$ \\
\hline Remaja & 2 & 6,150 & 6,150 & 1,4849 & 5,1 & 7,2 \\
\hline Dewasa & 13 & 7,831 & 8,100 & 1,7613 & 5,3 & 12,1 \\
\hline Lansia & 33 & 8,273 & 8,500 & 1,3558 & 4,6 & 11,1 \\
\hline
\end{tabular}


Tabel 3

Kadar Hemoglobin Pada Pasien Gagal Ginjal Kronik yang Menjalani Hemodialisis Berdasarkan Lama Sakit

\begin{tabular}{ccccccc}
\hline Lama Sakit & $\mathbf{n}$ & $\begin{array}{c}\text { Mean } \\
\text { (gr/dl) }\end{array}$ & $\begin{array}{c}\text { Median } \\
\text { (gr/dl) }\end{array}$ & $\begin{array}{c}\text { SD } \\
(\mathbf{g r} / \mathbf{d l})\end{array}$ & $\begin{array}{c}\text { Min } \\
(\mathbf{g r} / \mathbf{d l})\end{array}$ & $\begin{array}{c}\text { Max } \\
(\mathbf{g r} / \mathbf{d l})\end{array}$ \\
\hline$\leq 3$ bulan & 2 & 6,750 & 6,750 & 0,6364 & 6,3 & 7,2 \\
\hline$>$ 3 bulan & 46 & 8,122 & 8,400 & 0,5182 & 4,6 & 12,1 \\
\hline
\end{tabular}

Tabel 4

Kadar Hemoglobin Pada Pasien Gagal Ginjal Kronik yang Menjalani Hemodialisis Berdasarkan Lama Hemodialisis

\begin{tabular}{ccccccc}
\hline Lama Sakit & $\mathbf{n}$ & $\begin{array}{c}\text { Mean } \\
\text { (gr/dl) }\end{array}$ & $\begin{array}{c}\text { Median } \\
(\mathbf{g r} / \mathbf{d l})\end{array}$ & $\begin{array}{c}\text { SD } \\
(\mathbf{g r} / \mathbf{d l})\end{array}$ & $\begin{array}{c}\text { Min } \\
(\mathbf{g r} / \mathbf{d l})\end{array}$ & $\begin{array}{c}\text { Max } \\
(\mathbf{g r} / \mathbf{d l})\end{array}$ \\
\hline$\leq 12$ bulan & 5 & 7,020 & 4,6 & 1,5944 & 4,6 & 8,6 \\
\hline$>12$ bulan & 43 & 8,186 & 5,1 & 1,4758 & 5,1 & 12,1 \\
\hline
\end{tabular}

\section{PEMBAHASAN}

Pada penelitian ini jenis kelamin laki-laki mempunyai kadar hemoglobin lebih tinggi dengan kategori anemia sedang dibandingkan dengan perempuan. dengan kategori anemia berat. Hal ini sesuai dengan teori yang menyebutkan bahwa wanita usia subur sering mengalami anemia, karena kehilangan darah sewaktu menstruasi dan peningkatan kebutuhan besi sewaktu hamil. Adanya siklus haid ini sehingga pada perempuan membutuhkan zat besi sebagai bahan penyusun hemoglobin lebih banyak daripada lakilaki. Hasil ini juga sesuai dengan penelitian yang menunjukkan anemia lebih banyak diderita perempuan dibandingkan laki-laki.

Berdasarkan umur, hasil penelitian ini menunjukkan bahwa semakin bertambah umur maka kadar hemoglobin semakin meningkat. Walaupun jika dilihat dari kadar hemoglobin terendah, didapatkan pada umur lansia. Hal ini tidak sejalan dengan teori yang mengatakan bahwa Fungsi ginjal akan berubah bersamaan dengan penambahan umur. Sesudah umur 40 tahun akan terjadi penurunan laju filtrasi glomerulus secara progresif hingga usia 70 tahun. Dengan adanya penuaan, ginjal menjadi berkurang kemampuannya dalam merespon perubahan cairan elektrolit yang akut. Diumur lansia resiko terjadinya anemia sangat besar. Semakin bertambah umur seseorang, semakin beresiko mengalami malnutrisi. Bila malnutrisi ini tidak ditangani dengan baik bisa berlanjut kekurangan energi, protein, zat besi dan nutrisi lain. Kekurangan nutrisi dapat berisiko anemia, mudah lelah dan menurunnya level imun. (Nurchayati, 2011; Oktaviani 2013). Hasil juga menunjukkan bahwa pada umur remaja dan dewasa juga didapatkan anemia berat dengan kadar hemoglobin terendah $<8$ gr/dl. Adanya anemia pada masa remaja dan dewasa ini bisa disebabkan adanya penyakit yang sudah mendasari sebelumnya misalnya inflamasi. Inflamasi akan memberikan efek negatif pada daya tahan eritrosit. Pada proses penuaan, sitokin sitokin pro inflamator, IL -6 , dan protein fase akut akan mengalami peningkatan kadar, bahkan pada orang yang sehat. IL -6 diketahui akan menginduksi pelepasan dari Heptidin. Oleh karena itu peningkatan usia akan meningkatkan angka kejadian anemia oleh karena proses inflamasi. Selain itu gaya hidup yang tidak baik seperti kebiasaan kekurangan cairan atau konsumsi makanan minuman yang mengandung zat 
nefrotoksik sehingga akan cepat menyebabkan penurunan fungsi sel-sel ginjal. (Senduk, 2016).

Berdasarkan frekuensi lama sakit, jumlah pasien yang menderita sakit > 3 bulan didapat lebih banyak dari yang sakitnya baru $<3$ bulan. Hal ini sejalan dengan teori yang menyebutkan bahwa gagal ginjal kronik adalah kerusakan ginjal $>3$ bulan, yaitu kelainan struktur histopatologi petanda kerusakan ginjal, meliputi kelainan komposisi darah dan urin atau uji pencitraan ginjal dan pada stadium akhir dibutuhkan terapi ginjal pengganti untuk mengambil alih fungsi ginjal dalam mengeliminasi toksin tubuh. Gagal ginjal kronik ditandai dengan kerusakan progresif dari massa ginjal dengan adanya sklerosis dan hilangnya nefron yang irreversibel yang terjadi dalam periode berbulan-bulan sampai menahun tergantung etiologi yang mendasarinya (PERNEFRI, 2012). Hasil ini sejalan juga dengan penelitian Mubarokah (2013) yang mendapat rata-rata lama sakit pada penderita sakit gagal ginjal adalah 3 tahun.

Hasil penelitian juga menunjukkan bahwa pada pasien yang sakit $\leq 3$ bulan mempunyai kadar hemoglobin yang lebih rendah dengan derajat anemia berat daripada yang sudah $>3$ bulan menderita sakit. Hal ini tidak sejalan dengan teori yang menyebutkan sakit terutama penyakit infeksi mempengaruhi metabolisme dan utilisasi zat besi yang diperlukan dalam pembentukan hemoglobin dalam darah. Kadar hemoglobin yang rendah ini bisa disebabkan karena kondisi pasien memang dalam kondisi yang parah karena sakit yang mendasari sebelumnya. Etiologi penyakit gagal ginjal ini antara lain karena hipertensi dan Diabetes Mellitus. (Permaesih, 2005; Battha; 2011). Penderita ginjal kronik biasanya juga terganggu asupan makanannya, misalnya karena nafsu makan hilang, mual, muntah dan gangguan saluran cerna sehingga jika tidak dipantau, kadar hemoglobin akan terus menurun sejalan dengan waktu penyakit.
Semakin menurunnya fungsi ginjal (ditandai dengan stadium yang bertambah dan GFR yang menurun), maka anemia akan semakin berat (Runtung, 2013).

Berdasarkan frekuensi lama hemodialisis, pasien yang mendapat hemodialisis lebih dari 12 bulan lebih banyak yaitu ada $43(81,2 \%)$ daripada yang kurang dari 12 bulan. Hasil ini sejalan dengan Mubarokah (2013) yang mendapat hasil $80 \%$, sebaliknya hasil Nurchayati (2011) yang mendapatkan frekuansi lama hemodialisis $>12$ bulan hanya $49,5 \%$ tetapi tidak sejalan dengan penelitian.

Berdasarkan keparahan anemia, didapat hasil kelompok pasien yang melakukan hemodialisis $\leq 12$ bulan mempunyai rata-rata kadar hemoglobin lebih rendah dengan kategori anemia berat. Hasil ini bertentangan dengan teori yang menyebutkan bahwa pasien gagal ginjal kronis yang menjalani hemodialisis jangka panjang akan banyak kehilangan darah karena tertinggal ke dalam dialiser (ginjal artifisial), perdarahan tersembunyi (occult blood loss), dan seringnya pengambilan darah untuk pemeriksaan laboratorium sehingga pasien dapat mengalami defisiensi besi, asam folat, bahkan defisiensi vitamin. Jumlah zat besi dalam sel darah merah yang hilang selama menjalani hemodialisis reguler antara 1,52,0 gram setiap tahunnya, jumlah ini jauh lebih besar daripada zat besi yang dapat diserap melalui makanan oleh saluran cerna. Jika keadaan ini terjadi secara terus menerus maka akan mengakibatkan berkurangnya kadar hemoglobin. Penelitian yang dilakukan di Makassar menunjukkan hemodialisis yang lama bisa menurunkan kadar hemoglobin (Runtung,2013). Pada penelitian ini dosis hemodialisis diberikan $2 \mathrm{x}$ dalam seminggu dengan lama hemodialisis 4-5 jam, sehingga total dalam satu minggu mendapatkan 8-10 jam durasi hemodialisis. Dari catatan rekam medis didapatkan ada 4 orang pasien yang pernah mendapatkan hemodialisis $3 \mathrm{x}$ perminggu 
selama 1-2 bulan, hal ini disebabkan kondisi fisik umum pasien yang lebih parah sehingga harus rawat inap. Setelah kondisinya membaik, pasien tersebut kemudian kembali mendapatkan hemodialisis $2 \mathrm{x} /$ minggu.

Kondisi optimal dialisis yang adekuat adalah dengan durasi 12-15 jam/minggu. Semakin lama dan sering proses hemodialisis, maka semakin banyak darah yang hilang yang menyebabkan anemia semakin berat. (Nurchayati, 2011 Senduk, 2016; ).

\section{KESIMPULAN}

Rata-rata kadar hemoglobin pasien perempuan $=7,794 \mathrm{gr} / \mathrm{dl}$ dan laki-laki $=$ 8,213 gr/dl. Rata-rata kadar hemoglobin pada pasien umur remaja $=6,150 \mathrm{gr} / \mathrm{dl}$, dewasa $=7,831 \mathrm{gr} / \mathrm{dl}$ dan lansia $=8,273$ gr/dl. Rata-rata kadar hemoglobin pada pasien yang lama sakit $\leq 3$ bulan $=6,750$ gr/dl dan yang lama sakit $>3$ bulan $=$ $8,122 \mathrm{gr} / \mathrm{dl}$. Rata-rata kadar hemoglobin pada pasien yang telah menjalani hemodialisis $\leq 12$ bulan $=7,020 \mathrm{gr} / \mathrm{dl}$ dan $>12$ bulan $=8,186 \mathrm{gr} / \mathrm{dl}$.

\section{SARAN}

Untuk peneliti selanjutnya agar melakukan pemeriksaan terhadap paramater hematologi lainnya untuk menentukan jenis anemia.

\section{DAFTAR PUSTAKA}

Alghythan, Abdullah Khader and Abbas $\mathrm{H}$. Alsaeed. Hematological changes before and after hemodialysis. Scientific Research and Essays Vol. 7(4), pp. 490-497, 30 January, 2012. Available online at http://www.academicjournals.org/SRE. DOI: $10.5897 /$ SRE11.1534. ISSN 19922248 @2012 Academic Journals

Adiatma, Dhanny Chandra. 2014. Prevalensi dan Jenis Anemia pada Pasien Penyakit Ginjal Kronik yang Menjalani Hemodialisis Reguler (Studi di RSUP Dr. Kariadi Semarang). Universitas Diponegoro.
Semarang

Afshar, Reza; Suzan Sanavi; Javad Salimi; Mahnaz Ahmadzadeh. Hematological Profile of Chronic Kidney Disease (CKD) Patients in Iran, in Pre-dialysis Stages and after Initiation of Hemodialysis. Saudi J Kidney Dis Transpl 2010;21(2):368-371 (C) 2010 Saudi Center for Organ Transplantation

Annisa Q.S. 2014. Analisis Kadar Hemoglobin Sebelum dan Sesudah Menjalani Hemodialisis. KTI. Poltekkes Kemenkes Palembang

Bain, Barbara J. 2011. Dacie and Lewis Practical Haematology, 11th edition. Elsevier Churchill Livingstone. London

Balalio, Eka Suprianta. 2012. Faktor-faktor yang Berhubungan dengan Kejadian Anemia pada Pasien Penyakit Ginjal Kronik yang Melakukan Hemodialisis di RS Labuang Baji Makassar. Universitas Muslim Indonesia. Makassar

Baradero, Mary,. 2008. Asuhan Keperawatan 'Klien Gangguan Ginjal'. ECG Jakarta

Bhatta S, Aryal G, Kafle RK. Anemia in chronic Kidney Disease Patients in Predialysis and Postdialysis. Journal of Pathology of Nepal (2001) Vol 1, 26 29. Diunduh dari URL :

http://nepjol.info/index.php/JPN/article/view/44 $\underline{46 / 3716}$

Hamidah, Anisatul; Anik Handayati; Eddy Haryanto. 2012. Korelasi Kadar Hemoglobin dengan Saturasi Transferin pada Gagal Ginjal Kronik yang Anemia. Analis Kesehatan Sains Vol.01, No.02. Surabaya

Hoffbrand A.V., Pettit J.E. 1987. Kapita Selekta: Haematologi Edisi 2. ECG. Jakarta

KDIGO Clinical Practice Guideline for Anemia in Chronic Kidney Disease. VOL 2 | ISSUE 4 | AUGUST (2) 2012

Kiswari, Rukman. 2014. Hematologi dan Transfusi. Erlangga. Jakarta 
Lerma, EV. 2015. Anemia of Chronic Disease and Renal Failure. Diunduh dari URL : http://emedicine.medscape.com/article/1 389854-overview\#showall

Mubarokah, Anita; Aywar Zamri, Armaidi Darmawan. 2013. Perbedaan kadar hemoglobin, ureum, kreatinin pre dan post hemodialisa selama 3 bulan menjalani hemodialisa pada penderita Gagal Ginjal Kronik di RSUD Raden Mattaher Jambi. Skripsi. Universitas Jambi.

National Kidney Foundation. 2006. Anemia and Chronic Kidney Disease. Diunduh dari URL: http://www.kidney.org/atoz/pdf/anemia. pdf

Nurchayati, Sofiana. 2011. Analisis Faktorfaktor yang Berhubungan dengan Kualitas Hidup Pasien Penyakit Ginjal Kronik yang Menjalani Hemodialisis di RSI Fatimah Cilacap dan RSUD Banyumas. Tesis. Universitas Indonesia. Jakarta

Oktiadewi, AA Ayu. 2012. Hubungan Kadar Hemoglobin dan Status Gizi dengan Kualitas Hidup Pasien Penyakit Ginjal Kronik Stadium 5 yang Menjalani Hemodialisis. Universitas Diponegoro. Semarang

\section{PERNEFRI. 2012. 5 5 $^{\text {th }}$ Annual Report of Indonesia Renal Registry. http://www.pernefriinasn.org/laporan/5t h\%20annual\%20report\%20\%20IRR\%20 $\underline{2012}$}

Rathod, Sunita G; Arvind K. Ade; Pravin P. Shekokar. 2014. A Sudy of Haematological Changes in Chronic Renal Failure. Scholars Journal of Apllied Medical Sciences, 2014; 2(4A):1232-1234. ISSN 2320-6691 (online). ISSN 2347-954X (Print)

Runtung, Yasinta; Abd Kadir; Akuilina Semana. 2013. Pengaruh Haemodialisa Terhadap Kadar Ureum, Kreatinin dan Haemoglobin pada Pasien GGK di ruangan Haemodialisa RSUP Dr Wahidin Sudirohusodo Makassar. elibrary Stikes Muhammadiyah
Gombong. Volume 2 Nomor 3 Tahun 2013. ISSN : 2302-1721

Sari, Novi Lovita; Valentina Meta Srikartika, Difa Intannia. 2015. Profil dan Evaluasi Terapi Anemia yang Menjalani Hemodialisa di BLUD RS Ratu Zalecha Martapura Periode Juli-Oktober 2014. Jurnal Pharmascience, Vol.2, No.1, Februari. ISSN : 2355-5386

Sastroasmoro S, Ismael S. 2002. Dasar-dasar Metodologi Penelitian Klinis. Binarupa Aksara; Jakarta.

Sekarwana, N; Gagal Ginjal Kronik pada Anak. Sari Pediatri, Vol. 6, No. 1 (Supplement), Juni 2004: 68-84

Senduk, Cindy R; Stella Palar dan Linda W.A. Rotty. 2016. Hubungan Anemia dengan Kualitas Hidup Pasien Penyakit Ginjal Kronik yang Sedang Menjalani Hemodialisis Reguler. Jurnal e-Clinic (eCi), Vol.4 No.1, Januari-April

Smeltzer, Bare. 2006. Medical Surgical Nursing Brunner and Suddarth Vol. 2. EGC. Jakarta

World Health Organization (WHO). 2011. Haemoglobin concentrations for the diagnosis of anemia and assessment of severity. Geneva: Vitamin and Mineral Nutrition Information System 